Vol. 1, No. 2, Juni 2021

\title{
PERENCANAAN PROSES PRODUKSI DAN LAYOUT FASILITAS PADA INDUSTRI TEMPE DI LINGKUNGAN PERESAK TEMPIT KELURAHAN AMPENAN TENGAH
}

\author{
Muhamad Ilhamudin \\ Fakultas Ekonomi dan Bisnis Universitas Mataram \\ ilham.alfian226.gmail.com \\ Weni Retnowati \\ Fakultas Ekonomi dan Bisnis Universitas Mataram \\ weni_nice@yahoo.co.id \\ Hilmiati \\ Fakultas Ekonomi dan Bisnis Universitas Mataram \\ hilmiatifauzi62@gmail.com \\ Rusminah \\ Fakultas Ekonomi dan Bisnis Universitas Mataram \\ rosewahyu99@gmail.com \\ Santi Nururly \\ Fakultas Ekonomi dan Bisnis Universitas Mataram \\ snururly@unram.ac.id
}

\section{Article History:}

Received: 25 Maret 2021

Revised: -

Accepted: 6 Juni 2021

DOI:

10.29303/abdimassangkabi ra.v1i2.29
Abstrak: Kegiatan usaha sebagian besar di kota Mataram merupakan usaha industri kecil dan menengah yang merupakan lahan pencaharian dari masyarakat kota. Usaha-usaha tersebut bercirikan usaha rumahan atau home industry. Salah satu home industri yang bergerak dalam sektor makanan di Kota Mataram adalah industri penghasil tempe di Lingkungan PeresakTempit Kelurahan Ampenan Tengah. Seperti halnya kebanyakan usaha rumahan, usaha tempe di lingkungan ini juga mengalami kendala dalam hal proses produksi dan layout fasilitas. Pengabdian ini ditujukan bagi produsen tempe agar mereka dapat mengembangkan kemampuannya dalam hal merencanakan alur proses yang benar, penataan layout fasilitas yang dapat meningkatkan efisiensi dan efektifitas kerja, serta penggunaan ruang dapat dihemat. Penyampaian materi dalam bentuk penyuluhan dan 
diskusi dengan memberikan materi pentingnya perencanaan proses produksi dan layout. Sebagai narasumber adalah Tim Pengusul Pengabdian pada Masyarakat Fakultas Ekonomi dan Bisnis Universitas Mataram. Permasalahan mitra antara lain: (1) Persaingan yang cukup ketat dengan banyaknya pesaing; dan (2) Para pengusaha tempe di Tempit belum cukup memiliki kemampuan perencanaan proses produksi dan layout fasilitas. Solusi yang ditawarkan adalah: (1) penyuluhan tentang perencanaan proses produksi (2) penyuluhan tentang layout fasilitas produksi. Pelaksanaan kegiatan ini berlangsung dalam masa pandemi covid 19 (Agustus 2020), maka untuk menghindari kerumunan massa maka dilakukan di beberapa tempat usaha yang masing-masing dihadiri 4 -5 orang di setiap tempat usaha. Hasil kegiatan ini adalah peserta yang berjumlah 15 orang yang terdiri dari pemilik/karyawan mendapatkan pengetahuan dan kemampuan merencanakan proses produksi dan layout fasilitas yang merupakan aspek penting untuk meningkatkan efisiensi dan efektifitas usaha di masa datang

Abstract: Most of the business activities in the city of Mataram are small and medium-sized industrial enterprises which are the livelihoods of the urban community. These businesses are characterized by a home business or home industry. One of the home industries engaged in the food sector in the city of Mataram is the tempe-producing industry in the Peresak Tempit, Ampenan Tengah Village. Like most home-based businesses, the tempe business in this neighborhood also experiences obstacles in terms of the production process and facility layout. This service is aimed at tempe producers so that they can develop their abilities in terms of planning the correct process flow, structuring facility layouts that can increase work efficiency and effectiveness, and save space usage. Presentation of material in the form of counseling and discussion by providing material on the importance of production process planning and layout. As a resource person is the Team of Proposal for Community Service, Faculty of Economics and Business, University of Mataram. Partner problems include: (1) Fairly tight competition with many competitors; and (2) Tempe entrepreneurs in Tempit do not have sufficient capacity in planning the production process and 


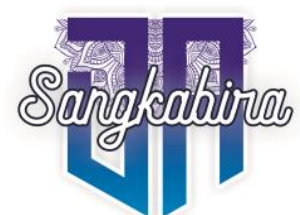

Vol. 1, No. 2, Juni 2021

layout of facilities. The solutions offered are: (1) counseling on the planning of the production process (2) counseling on the layout of production facilities. The implementation of this activity took place during the COVID-19 pandemic (August 2020), so to avoid crowds, it was carried out in several business places, each of which was attended by 4-5 people at each place of business. The result of this activity is that 15 participants consisting of owners/employees gain knowledge and ability to plan production processes and facility layouts, which are important aspects of increasing the efficiency and effectiveness of future businesses

Kata Kunci: perencanaan, produksi, layout tempe

Keywords: planning, production, layout, tempe.

\section{PENDAHULUAN}

Peran Usaha Mikro, Kecil, dan Menengah dalam perekonomian nasional sangatlah besar. Hal itu sudah tidak dapat diragukan lagi. Menteri Koperasi dan Usaha Kecil Menengah, Hasan dalam Republika Online (2013) menyatakan bahwa jumlah usaha tersebut di Indonesia mencapai sekitar 56,5 juta, dan 99,8 persennya adalah dari sektor UMKM. Oleh karena itu, UMKM di Indonesia berkontribusi sebesar 97 persen dalam penyerapan tenaga kerja.

Industri kecil banyak berkembang di kota Mataram NTB dengan berbagai jenis produk yang dihasilkan. Industri kecil di wilayah ini sebahagiannya berbasis home industry, yakni kegiatan usaha dilakukan di rumah-rumah secara turun-temurun. Salah satu industri kecil dalm sektor makanan di Kota Mataram adalah sentra industri penghasil tempe di Peresak Tempit Lingkungan Kelurahan Ampenan Tengah.

Pada umumnya permasalahan yang dihadapi oleh pengusaha kecil berkaitan dengan masalah kemampuan tatakelola manajemen atau pengolahan usaha yang kurang profesional. Umumnya usaha masih dikelola dengan menggunakan keluarga sebagai pengelolanya. Masalah lainnya meliputi struktur permodalan, produksi, dan pemasaran. Secara tehnis masalah masalah tersebut adalah belum adanya manajemen yang baik, masalah penyusunan rencana bisnis, sistem administrasi keuangan dan masalah akses ke teknologi, selera konsumen yang mudah berubah, masalah bahan baku, tingginya harga bahan baku, masalah inovasi, perbaikan kualitas barang dan efisiensi (Aziz, 2017). Padahal, usaha kecil atau home industry dapat dikelola secara profesional.

Industri tempe di Tempit pada umumnya masih dilakukan secara tradisional. Meskipun demikian produk tempe yang dihasilkan memiliki cita rasa yang khas, dengan kualitas dan kadar gizi yang tinggi. Proses pembuatan tempe di sentra industri ini seperti halnya pembuatan tempe 
tradisional pada umumnya. Proses itu dimulai dengan pembersihan kedelai, merebus kedelai, merendam kedelai yang telah matang sampai benar-benar mengental. Langkah berikutnya adalah menggiling dan kemudian dikukus dengan dandang kukusan. Kedelai didinginkan, kemudian dicampur dengan ragi tempe. Ragi tempe ditaburkan pada kedelai dingin lalu dicampur hingga merata. Industri tempe di wilayah yang bersuhu panas ini, fermentasi menjadi lebih cepat. Tahap berikutnya adalah pengemasan setelah tempe dicampur ragi, memeram hingga kapang tumbuh merata sehingga merekat satu sama lain. Terakhir tempe sudah jadi dan siap dikonsumsi.

Pelaku industri sudah memahami betul proses produksi ini karena diwariskan secara turun-temurun. Seperti halnya kebanyakan usaha kecil, UMKM penghasil tempe di Tempit Kelurahan Ampenan Tengah juga mengalami kendala dalam hal pengelolaan proses produksi dan layout. Pengabdian ini ditujukan bagi UMKM penghasil tempe agar pengusaha bersangkutan dapat mengembangkan kemampuannya dalam hal mengelola usahanya, melakukan kegiatan proses produksi yang efektif dan efisien, pengaturan layout fasilitas operasi, dan mendapatkan keuntungan maksimal. adalah:

Solusi yang ditawarkan untuk menanggulangi permasalahan tersebut

a) Memberikan penyuluhan dalam manajemen produksi menyeluruh.

b) Memberikan penyuluhan yang menekankan kepada aspek perencanaan proses produksi, dan layout fasilitas produksi.

Dalam pelaksanaan kegiatan ini, partisipasi aktif dari pemilik dan pengusaha tempe di Tempit sangat diperlukan dalam menerima ilmu pengetahuan melalui penyuluhan, sehingga sehingga selanjutnya peserta dapat mengelola kegiatan produksi dengan lebih baik.

Melalui kegiatan pengabdian ini diharapkan dapat mencapai hasil keluaran (outcome) sebagai berikut:

a) Meningkatnya pengetahuan pemilik dan karyawan mengenai pengelolaan produksi yang efektif dan efisien.

b) Pemilik dan karyawan memperoleh pengetahuan mengenai aspek perencanaan produksi, dan layout.

\section{METODE PELAKSANAAN KEGIATAN}

Penyampaian materi dalam kegiatan pendampingan UMKM industri tempe di Tempit dengan memberikan penyuluhan tentang pentingnya pengelolaan produksi secara umum, perencanaan produksi, dan layout. Penyampaian materi juga akan dilengkapi dengan diskusi.

Sebaga narasumber adalah Tim Pengusul Pengabdian pada Masyarakat (PPM) Fakultas Ekonomi dan Bisnis Universitas Mataram. Untuk menunjang kelancaran kegiatan ini, maka akan dikoordinasikan 
dengan lembaga terkait, yaitu: LPPM Universitas Mataram, Dekan Fakultas Ekonomi dan Bisnis Universitas Mataram, dan pengelola usaha tempe di Tempit.

Evaluasi dari keberhasilan pelatihan ini akan dilihat dari kehadiran peserta dan keaktifan peserta dalam memberi respon terhadap materi yang diberikan selama penyuluhan berlangsung.

\section{Tahap Pendahuluan}

\section{HASIL DAN PEMBAHASAN}

Kegiatan pengabdian ini merupakan kegiatan yang mengambil topik yang hampir sama dengan kegiatan pengabdian sebelumnya, hanya saja pada lokasi yang berbeda. Topik yang dimaksud adalah manajemen operasional yang lebih menekankan pada konteks perencanaan proses produksi dan layout fasilitas produksi, sementara kegiatan tahun lalu yang berlokasi di Pejeruk Abian menyampaikan hampir keseluruhan aspek manajemen operasional yang meliputi aspek forecasting, perencanaan produksi, proses dan layout, manajemen persediaan dan produktivitas, dan lain lain.

Kegiatan pendahuluan dilakukan dalam bentuk survey untuk melihat sejauhmana pelaku industri memahami dan mengimplementasi aspek produksi pada usahanya. Dari survey diketahui bahwa pelaku industri sudah memiliki pengetahuan dan keterampilan dalam mendesain tehnik proses dengan menggunakan peralatan sederhana dan kemampuan me-layout fasilitas produksi dengan cara yang sudah diturunkan oleh generasi sebelumnya. Hanya saja pelaku usaha perlu mendapatkan pengetahuan yang baru sejalan perkembangan ilmu manajemen produksi itu sendiri. Proses produksi dan layout yang baik akan membantu usaha tersebut untuk meningkatkan efisiensi dan kualitas produk yang dihasilkan.

Dari hasil survey pendahuluan, kemudian dibuat suatu rancangan materi yang relevan, sederhana dan mudah dimengerti. Materi pokok berkisar pada konsep perencanaan produksi dan perencanaan layout fasilitas. Kedua topik ini merupakan bagian perencanaan sistem produksi yang mempunyai peran besar dalam membangun biaya operasi dan kuantitas produk yang dihasilkan perusahaan.

\section{Tahap Penyuluhan}

Sebelum dilakukan penyuluhan, berbagai hal menyangkut teknis pelaksanaan dipersiapkan seperti penentuan jumlah peserta, tempat, dan waktu penyuluhan. Kegiatan penyuluhan dilaksanakan pada bulan Agustus 2020. Mengingat wabah covid 19 masih membayangi kehidupan kesehatan masyarakat kota Mataram, maka tehnis pelaksanaan penyuluhan dilakukan dengan mengikuti standar protokol kesehatan. Penyuluhan diberikan kepada pelaku usaha dan karyawannya ditempat 
mereka bekerja. Dengan demikian kegiatan ini dilakukan dibeberapa tempat usaha dengan tujuan untuk menghindari kerumunan massa dan dilakukan di tempat terbuka. Jumlah peserta kegiatan adalah 15 orang dari unsur pelaku usaha dan pekerja UMKM tempe di Tempit Peresak kelurahan Ampenan Tengah.

Adapun materi penyuluhan adalah sebagai berikut:

a) Pentingnya manajemen produksi

b) Perencanaan sistem produksi

c) Perencanaan proses produksi

d) Perencanaan layout

Setelah materi disampaikan maka dilakukan tanya jawab tentang hal-hal yang berhubungan dengan materi maupun pengalaman usaha peserta. Kegiatan tersebut sangat partisipatif dan kondusif kalau melihat respons yang antusias dari peserta yang memberikan pertanyaan atau berbagi pengalaman di antara mereka, dan memberi solusi atas persoalan yang dihadapi.

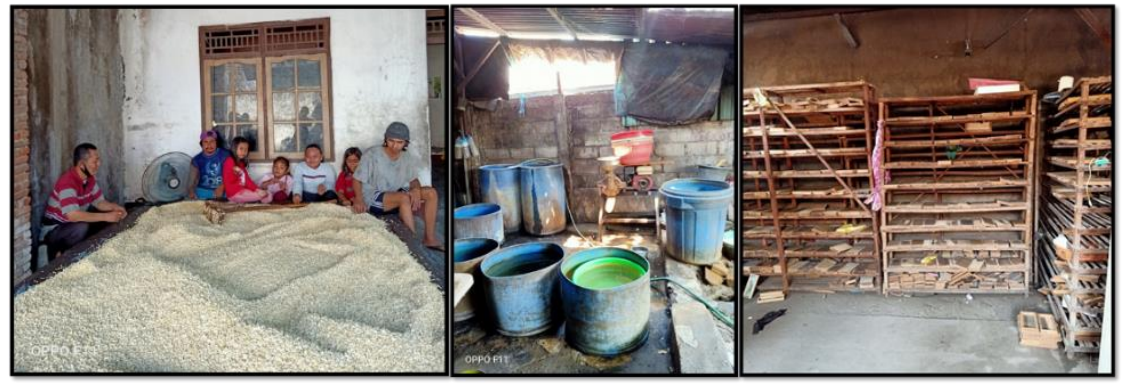

Gambar 1. Kegiatan Penyuluhan

\section{Kesimpulan}

\section{KESIMPULAN DAN SARAN}

Penyuluhan yang dilakukan tim Pengabdian Kepada Masyarakat FEB Unram telah dilakukan dengan memfokuskan pada peningkatan pengetahuan pelaku usaha dan karyawan industri tempe pada aspek manajemen produksi. Manajemen produksi difokuskan pada aspek perencanaan proses produksi dan layout fasilitas. Kegiatan berlangsung partisipatif, persoalan lapangan banyak berhubungan dengan pengetahuan ini. Peserta ada yang menyampaikan pertanyaan, berbagi pengalaman, dan mengajukan solusi sendiri atas masalah produksi yang dihadapi. Pengetahuan ini membantu mereka membangun keunggulan bersaing yang bersumber dari aktivitas produksi yang lebih efektif, efisien, dan lebih berkualitas.

\section{Saran}

Kegiatan pengabdian berikutnya disarankan untuk menekankan pada penyampaian pengetahuan yang lebih mendalam pada aspek-aspek 


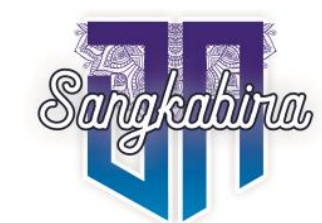

Vol. 1, No. 2, Juni 2021

manajemen produksi. Konsep manajemen produksi sangat luas, tidak bisa dipahami dengan sekali kegiatan namun berkesinambungan. Pemahaman yang lebih detail membantu pelaku industri tempe Tempit Peresak untuk dapat mengantisipasi ketatnya persaingan dalam industri. Mereka membutuhkan daya saing yang dibangun pada lapisan kegiatan produksi/operasi.

\section{UCAPAN TERIMA KASIH}

Tim pengabdian masyarakat mengucapkan terima kasih kepada Fakultas Ekonomi dan Bisnis, Lembaga Penelitian dan Pengabdian Universitas Mataram yang telah memberikan memberi dukungan financial sehingga kegiatan pengabdian ini dapat terlaksana. Juga ucapan terima kasih ditujukan kepada para pemilik usaha di industri tempe di lingkungan peresak tempit Kelurahan Ampenan Tengah atas kerjasamanya sehingga kegiatan pengabdian pada masyarakat ini dapat berjalan lancar.

\section{DAFTAR PUSTAKA}

Aziz N. 2007. Penerapan Sisitem Informasi Pemasaran pada Usaha Kecil Menengah (UKM) di Kota Malang. Universitas Muhammadiyah. Malang.

Ikatan Akuntan Indonesia. 2009. Standar Akuntansi Keuangan. Salemba Empat. Jakarta.

Kementerian Koperasi dan Usaha Kecil Menengah, 2008. UU No. 20 Tahun 2008 Tentang Usaha Mikro Kecil dan Menengah. www.bi.go.id

Martowardoyo, Agus. "Bank Indonesia Klaim Peduli Nasib UMKM di Indonesia". http://www.merdeka.com.

Santia, Masayu Praba. 2014. Analisis Strategi Pemasaran untuk Meningkatkan Penjualan Tahu pada UD. Putra Abian Tubuh, Universitas Mataram. Mataram.

Tambunan, TH Tulus. 2003. Perekonomian Indonesia. Ghalia Indonesia. Jakarta. 